\title{
IDENTIFIKASI BANGUNAN-BANGUNAN BERSEJARAH DI DESA TANDEM KECAMATAN HAMPARAN PERAK
}

\author{
Oleh: \\ Hafnita Sari Dewi Lubis \\ Rehan Zahara
}

\begin{abstract}
ABSTRAK
Penelitian ini bertujuan untuk mengetahui bagaimana sejarah berdirinya bangunan bangunan bersejarah di Desa Tandem Kecamatan Hamparan Perak Kabupaten Deli Serdang, mengidentifikasi bangunan - bangunan bersejarah di Desa Tandem Kecamatan Hamparan Perak Kabupaten Deli Serdang, bagaimana pelestarian yang dilakukan pihak pemerintah dan masyarakat setempat terhadap bangunan - bangunan bersejarah di Desa Tandem Kecamatan Hamparan Perak Kabupaten Deli serdang. Metode yang digunakan dalam penelitian ini adalah metode Penelitian Lapangan (field research) yaitu, peneliti langsung terjun kelapangan dengan menggunakan teknik wawancara, observasi dan studi dokumen dan Studi Pustaka (library researh) yaitu dengan membandingkan buku dan dokumen yang relevan. Dalam hal ini keadaan bangunan - banguan bersejarah yang ada di Desa Tandem Kecamatan Hamparan Perak Kabupaten Deli Sedang yang didirikan sekitar tahun 1889 di mulai dari proses dibukanya perkebunan tembakau deli untuk mempermudah pengelolaan tembakau maka dibangunlah kantor administrasi, rumah menager, gudang pupuk, gudang barang, rumah staf, gudang pemeraman tembakau, kantor afdeeling, rumah karyawan, poliklinik, sekolah dan mesjid. Dari kedua wilayah tersebut bangunan yang terdapat di Desa Tandem Hulu terlihat lebih terawat jika di bandingkan dengan bangunan di Desa Tandem Hilir.
\end{abstract}

Kata Kunci : Peninggalan Bersejarah, Desa Tandem 


\section{PENDAhuluan}

Bangunan - bangunan bersejarah di Desa Tandem merupakan bangunan yang meyisakan kehidupan pemerintah kolonial Belanda dalam membangun perkebunan tembakau pada masa kolonial Belanda, bangunan bersejarah tersebut menjadi bukti bahwa dahulunya terdapat suatu kehidupan perindustrian tembakau di Desa Tandem Kecamatan Hamparan Perak Kabupaten Deli Serdang. Untuk melindungi situs bersejarah tersebut maka pemerintah mengeluarkan Undang-Undang Republik Indonesia nomor 11 tahun 2010 tentang Cagar Budaya, dikatakan bahwa Cagar Budaya adalah warisan budaya bersifat kebendaan berupa benda Cagar Budaya, Bangunan Cagar Budaya, Struktur Cagar Budaya, Situs Cagar Budaya, dan Kawasan Cagar Budaya di darat dan/atau di air yang perlu dilestarikan keberadaannya karena memiliki nilai penting bagi sejarah ilmu pengetahuan, pendidikan, agama, dan/atau kebudayaan melalui proses penetapan.

Undang-Undang Cagar Budaya Nomor 11 Tahun 2010 menimbang pada ayat C menyatakan bahwa Cagar Budaya berupa benda, bangunan, situs, dan kawasan perlu dikelola oleh pemerintah dan pemerintahan daerah dengan meningkatkan peran serta masyarakat untuk melindungi, mengembangkan, dan memanfaatkan cagar budaya. Dengan adanya UU tentang Cagar Budaya tahun 2010 itu, maka pemerintah dan masyarakat di sekitar situs atau bangunan tersebut diarahkan untuk melindungi, melestarikan maupun memanfaatkan situs bersejarah itu. Namun meskipun demikian, masih banyak bangunan-bangunan yang dianggap telah memiliki kriteria bangunan bersejarah atau bangunan cagar budaya yang masih belum dimasukkan kepada bagian bangunan cagar budaya yang dilindungi oleh undang-undang salah satunya ialah bangunan peninggalan PTPN II yang terdapat di Desa Tandem Kecamatan Hamparan Perak KabupatenDeli Serdang.

Maka dari itu, peneliti merumuskan masalah yaitu bagaimana sejarah berdirikannya bangunan-bangunan bersejarah di Desa Tandem Kecamatan Hamparan Perak Kabupaten Deli Serdang. Mengidentifikasi bangunan-bangunan bersejarah di Desa Tandem Kecamatan Hamparan Perak Kabupaten Deli Serdang. Bagaimana pelestarian yang dilakukan pemerintah dan masyarakat setempat terhadap bangunan bangunan bersejarah di Desa Tandem Kecamatan Hamparan Perak Kabupaten Deli Serdang. Metode yang digunakan dalam penelitian ini adalah metode Penelitian Lapangan (field research) dan Studi Pustaka (library researh) 


\section{II.PEMBAHASAN}

\section{A. Sejarah Berdirinya Bangunan-Bangunan Bersejarah di Desa Tandem}

Berkembangnya perkebunan tembakau di Deli, membuat pemodal asing ingin menanamkan modalnya untuk perkebunan Deli. Sehingga perkembangan perusahanan perkebunan tembakau terus berkembang dan lahan penanaman tembakau terus diperluas keberbagai daerah.

Dengan dibukanya perkebunan tembakau di Deli, maka di bentuklah berbagai daerah perkebunan di Deli. Wilayah yang cocok untuk dijadikan lahan perkebunan yaitu wilayah Sei Wampu si Langkat dan Sei Ular di Serdang. Salah satunya daerah yang cocok untuk perkebunan tembakau yang berada antara Sei Wampu dengan Sei Ular (sebutan saat ini) yaitu Hamparan Perak yang wilayahnya meliputi Desa Tandam Hilir dan Tandam Hulu. Pembukaan perkebunan tembakau di kawasan ini di perkirakan pada tahun 1884 dengan di bukanya berbagai daerah perkebunan di daerah ini.

Sejak dibukanya perkebunan di daerah tersebut, maka mulailah dibangun infrastruktur untuk mendukung bekerjanya ekonomi perkebunan. Jalan, jembatan, pelabuhan, dan bermacam fasilitas pelayanan perkebunan seperti sarana tempat pemukiman buruh dan staf perkebunan. Adanya berbagai fasilitas yang telah dibangun untuk kelancaran pelaksanaan perkebunan yaitu dibangunnya pembangunan rel kereta api untuk mengangkut kayu dan atap yang akan disimpan didalam gudang. Adapun rute yang dilakukan kereta api tersebut yaitu Buluh Cina- Tandam Hilir - Kota Datar - Gudang Atap- Kampung Perkotaan. Atap dan kayu yang telah diangkut, yang akan dijadikan pembangunan di perkebunan tembakau di Desa Tandem yang merupakan cabang dari unit perkebunan tembakau di Desa Buluh Cina.

\section{B. Bangunan - Bangunan Bersejarah Di Desa Tandem Hulu}

\section{Bangunan Rumah Manajer Perkebunan}

Bangunan rumah manajer yang dibangun pada masa pemerintahan Kolonial Belanda, diperkirakan memiliki luas $1083 \mathrm{~m}^{2}$ dan juga memiliki halaman yang cukup 
luas. Halaman rumah manajer perkebunan ini juga di tanami berberapa jenis tumbuhan menandakan bahwa pada masa pemerintahan Belanda dalam hal pembangunan rumah juga memperhatikan lingkungan sekitar rumah, sehingga rumah yang ditempati manajer perkebunan kelihatan sejuk. Rumah manajer perkebunan berbentuk seperti bangunan klasik khas Belanda yang berbahan dasar bangunan rumah tersebut dari batu. Bagian depan rumah atau pintu masuk rumah dibangun lebih tinggi dari dasar halaman rumah namun rumah manajer ini tidak berbentuk rumah panggung melainkan lantai rumah yang tinggi. Rumah manajer perkebunan ini juga terdapat banyak jendela yang berbentuk jendela sisir dan bentuk jendela panjang, memiliki lubang ventilasi yang luas berbentuk kubus dan terletak di bagian atas jendela, ventilasi ini terbuat dari kayu. Bentuk rumah manajer perkebunan ini sampai sekarang masih sama dengan bentuk aslinya, namun ada sedikit renofasi pada bagian atap rumah dikerenakan atap yang tidak kuat dan mudah bocor. Bagian dalam rumah manajer perkebunan ini sangat luas, ruangan - ruangan terbagi atas ruang tamu, ruangan rapat, kamar tidur berjumlah 2 , ruangan makan dan juga ruangan dapur dengan lantai yang mengilat terbuat dari keramik. Bentuk bangunan rumah manajer masih sama dengan bentuk aslinya. Hingga sekarang bangunan ini berfungsi sebagai tempat tinggal manajer perkebunan.

\section{Bangunan Perkantoran Administrasi}

Bangunan ini dibangun pada masa pemerintahan Kolonial Belanda, namun berdasarkan penelitian bangunan perkantoran tidak diketahui kapan tahun berdirinya, diperkirakan bangunan tersebut dibangun sekitar abad ke 19. Bangunan perkantoran perkebunan di Desa Tandem mengalami renovasi pada tahun 1996, dan mengalami penambahan luas ruangan sehingga luas bangunan perkantoran administarsi ini menjadi500 $\mathrm{m}^{2}$. Bangunan ini dahulunya dijadikan sebagai kantor perkebunan di desa Tandem, hingga sampai sekarang ini, masih digunakan sebagai kantor administrasi perkebunan. Meski telah di renovasi bangunan perkantoran administrasi masih tampak bergaya arsitektur belanda karena bentuk asli dari bangunan ini tetap dipertahankan oleh pihak perkebunan.

\section{Bangunan Gudang Pupuk}

Bangunan gudang ini diperkirakan di bangun pada tahun 1940.Bangunan gudang pupuk berbentuk rumah panggung yang terbuat dari kayu berpondasikan beton dan 
beratapkan seng. Memilki luas $182 \mathrm{~m}^{2}$ dan berbentuk persegi panjang berada dibelakang kantor administrasi dapat menyimpan 1000 ton pupuk untuk persediaan perkebunan tembakau pada masa kolonial Belanda. Hingga sekarang bangunan gudang pupuk ini masih di pergunakan untuk menyimpan pupuk. Namun pupuk yang di simpan tidak sebanyak pada masa kolonial Belanda di karenakan berkurangnya lahan perkebunan pada saat ini.

\section{Bangunan Gudang Barang}

Bangunan gudang barang ini terdapat di depan bangunan gudang pupuk. Bangunan gudang barang diperkirakan di bangun pada tahun 1940. Bangunan gudang barang berbentuk rumah panggung yang berpondasikan beton dan beratapkan seng. Bentuk bangunan gudang barang hampir sama dengan gudang pupuk yaitu persegi panjang. Luas bangunan gudang barang $384 \mathrm{~m}^{2}$.Bangunan gudang barang yang berbentuk persegi panjang dibagi menjadi beberapa ruang yaitu ruangan untuk tempat penyimpanan alat perkebunan seperti senior, cangkul, sekop, mesin air dan alat perkebunan lain sebagainya. Bangunan gudang barang sampai sekarang masih diperguankan untuk menyimpan barang-barang atau alat-alat perkebunan.

\section{Bangunan Rumah Staf Perkebunan}

Salah satunya bangunan yang dibangun pada masa pemerintahan kolonial Belanda merupakan perumahan staf perkebunan yang dibangun sekitar tahun 1940. Rumah staf perkebunan di kawasan emplasmen ini berjumlah 5 unit dengan gaya arsitektur yang sama. Rumah staf perkebunan dahulunya juga digunakan sebagai tempat tinggal staf perkebunan. Namun berdasarkan penelitian tidak dapat diketahui siapa pertama kali yang menempati rumah tersebut. Bangunan rumah staf yang dibangun pada masa pemerintah kolonial Belanda, diperkirakan memiliki luas $459 \mathrm{~m}^{2}$ dan juga memiliki halaman yang sederhana. Halaman rumah staf perkebunan juga ditanami beberapa jenis tanaman bunga. Bentuk rumah staf perkebunan ini berbentuk seperti rumah couple. Namun rumah tersebut ditempati hanya satu keluarga dan bahan dasar dalam pembangunan rumah tersebut dari batu Dan kayu. Bagian depan rumah 
terdapat teras rumah pada bagian atap teras berbentuk teritisan genteng yang membentuk segitiga layang-layang. Tipe rumah ini dibangun dengan banyak jendela. Sehingga ventilasi udara dibuat hanya seperti lubang - lubang kecil, dan rumah staf perkebunan ini memiliki atap yang berbentuk segitiga. Atap rumah staf perkebunan terbuat dari genteng. Bentuk rumah tersebut sampai sekarang masih sama dengan aslinya.

\section{Bangunan Gudang Pemeraman Tembakau}

Gudang ini diperkirakan dibangun pada abad ke 18 namun, mengalami renovasi pada tahun 1940 dan luas gudang pemeraman tembakau $3.976 \mathrm{~m}^{2}$. Gudang pemeraman tembakau terbagi atas beberapa bagian yaitu bagian gudang pilih, gudang show room , kamar mesin embun. Bentuk bangunan pada bagian gudang pilih berbentuk persegi panjang yang setiap gangnya terbuat dari kayu yang sangat kokoh. Gudang pilih berfungsi untuk kegiatan sortasi yang terdiri dari belah, pilih dan gambang. Belah, pilih dan gambang merupakan rangkaian pekerjaan lanjutan dari fermentasi. Adapun ruang sortasi terdiri dari tiga gang kamar pilih yang dibawahi oleh satu orang asisten gang kamar pilih Berdasarkan temuan penulis, pada bangunan gudang tembakau ini terdapat dua mesin pres yang dahulunya digunakan sebagai pengepres tembakau yang hendak dikemas. Setelah tembakau di susun kedalam peti lalu tembakau tersebut dipres mengunakan mesin pres tersebut. Setelah selesai dalam pengemasan di dalam peti tembakau dimasukkan kedalam ruangan yang beruap atau bertempratur dingin. Selain mesin pres penulis juga menemukan mesin uap, mesin uap ini dahulunya di gunakan oleh Pemerintah Belanda untuk memberikan hawa dingin pada tembakau. Bangunan asli gudang pemeraman tembakau ini terdapat pada gudang pilih yang berdindingkan beton dan tempat pemilihan tembakau terbuat dari kayu. Adapun bangunan tambahan pada bagian gudang show room dan gudang embun. Kondisi asli bangunan gudang pemeraman tembakau mengalami sedikit kerusakan, seperti adanya kaca yang sudah pecah dan kayu - kayu pada gudang yang hampir rusak. Perlunya perhatian dari 
masyarakat setempat dan pemerintah perkebunan agar dapat menjaga dan melestarikan banguan tersebut agar tidak terjadi kerusakan yang lebih parah.

\section{Bangunan Mesjid Perkebunan}

Mesjid Baitu Sa'Adah dibangun sekitar tahun 1940 an. Awalnya mesjid ini berbahan dasar kayu dan beratapkan genteng, bentuk awal mesjid Baitu Sa'Adah seperti rumah panggung. "Dahulunya Mesjid ini sering di sebut dengan Mesjid VOC karena menurut kesaksiannya Mesjid ini awalnya di bangun oleh pemerintah Belanda untuk tempat ibadah buruh perkebunan. Namun, setelah perkebunan tidak lagi dikelola oleh pemerintah Belanda maka, masyarakat setempat mengganti nama Mesjid VOC menjadi Mesjid Baitu Sa’Adah”. (Misbah Ribut, Wawancara, 20 April 2017).

\section{Bangunan Kantor Afdeeling}

Bangunan kantor afdeeling ini dibangun sekitar tahun 1940 an. Luas areal bangunan ini sekitar $935 \mathrm{~m}^{2}$. Dahulunya kantor afdeeling ini digunakan sebagai tempat rapat dan membicarakan soal perkembangan perkebunan. Semua manajer perkebunan berkumpul di kantor afdeeling ini. Hingga sekarang bangunan ini masih dipergunakan seperti dahulunya. Bentuk kantor afdeeling ini berbentuk kubus dan atap bangunan ini berbentuk seperti limas. Tipe bangunan kantor afdeeling ini dibangun dengan banyak jendela. Sehingga ventilasi udara di buat bertutupkan kaca dan bangian depan pintu di buat tinggi. Bentuk bangunan kantor afdeeling sampai sekarang masih sama dengan aslinya, hanya ada penambahan semen pada teras belakang dan genteng yang sudah pernah bocor. Kondisi kantor afdeeling masih terawat dengan baik.

\section{Bangunan Sekolah SMP Negeri 3 Hamparan Perak}

Bangunan sekolah SMP Negeri 3 Hamparan Perak ini merupakan salah satu bangunan yang didirikan oleh pemerintah Belanda pada masa kolonial Belanda. Bangunan sekolah SMP Negeri 3 Hamparan Perak dijadikan sekolah dasar. "Dahulunya sekolah SMP Negeri 3 Hamparan Perak ini di berinama sekolah rakyat jenjang pendidikannya hanya sampai tiga tahun. Dari hasil penelitian tidak tahu pasti 
tahun berapa didirikannya sekolah SR (Sekolah Rakyat) ini. Namun, dari penjelasan kakek Misbah Ribut sekolah ini sudah berdiri sejak tahun 1950 an.” ( Misbah Ribut, Wawancara, 20 April 2017).

\section{Bangunan - Bangunan Bersejarah Si Desa Tandem Hilir}

\section{Bangunan Pabrik Gula Kwala Mudu}

Bangunan pabrik gula kwala madu ini terdiri dari bangunan Boiler tempat penguapan air untuk menjalankan mesin penggiling tebu, bangunan Boiler ini di bangun oleh pemerintah Indonesia sekitar tahun 1960 dan mesin Uap yang digunakan berasal dari Cina dan juga Jepang. Selain bangunan Boiler terdapat juga bangunan penyimpanan mesin untuk menggiling tabu menjadi gula, bangunan tersebut dibangun sekitar tahun 1960 danmulai digunakan pada tahun 1980 mesin penggiling yang letaknya sebelah kanan adalah buatan dari Jepang sedangkan mesin yang letahnya sebelah kiri adalah buatan dari Cina. Bangunan Pabrik Gula Kwala Madu ini memiliki luas sekitar 1 Hektar, kondisi bangunan pabrik gula kwala madu masih terawat terlihat dari bentuk bangunan dan mesin - mesin yang ada pada bagian pabrik. Pabrik gula kwala madu sampai sekarang masih aktif mengiling tebu dan memproduksi gula, meski pun dalam penggilingan tidak lagi setiap bulan, waktu penggilingan biasanya hanya dua kali setahun dalam satu tahun. penggilingan tebu terjadi ketika tebu - tebu yang di tanam sudah bisa di giling dan biasanya tebu yang di giling mencapai 500 ton.

\section{Bangunan Laboraturium Pabrik Gula Kwala Madu}

Bangunan Laboratorium ini merupakan bagian pokok dari pabrik gula kwala madu untuk mengetahui mutu dan keterjaminan gula yang di produksi oleh pabrik gula kwala madu. Bangunan laboratorium di bangun pada tahun 1961 bangunan laboratorium di rancang sedemikian rupa agar tetap menjaga kebersihan bangunan laboratoriun berdiri di tanah seluas $150 \mathrm{~m}^{2}$. Pada ruangan bangunan Laboratorium terdapat alat - alat kimia untuk menguji mutu gula yaitu lemari asam, lemari pemanas, dan jenis alat penguji lainnya. 


\section{Bangunan Perkantoran Administrasi Perkebunan Desa Tandem Hilir}

Bangunan perkantoran administrasi ini dibangun pada masa kolonial Belanda, namun berdasarkan penelitian bangunan perkantoran tidak dapat diketahui kapan tahun berdirinya, namun dapat diperkirakan bangunan perkantoran administrasi ini sudah berdiri sejak abad ke 19. Bangunan perkantoran administrasi perkebunan Desa Tandem Hilir mengalami renovasi pada tahun 1997, dan mengalami penambahan luas ruangan. Sehingga luas perkantoran administrasi ini menjadi $800 \mathrm{~m}^{2}$. Dahulunya bangunan kantor perkebunan hanya terdiri dari dua ruangan yaitu ruangan menajer dan ruangan rapat, setelah ada perenovasian bangunan kantor di tambah dengan ruangan untuk para pegawai perkebunan. Terlihat pada gambar gaya asrsitektur perkantoran administrasi ini menunjukkan gaya arsitektur pada masa sekarang. Dapat dilihat bahwa bangunan kantor administrasi tidak terlihat lagi bentuk aslinya karena telah di renovasi.

\section{Bangunan Poliklinik Perkebunan Desa Tandem Hilir}

Bangunan poliklinik yang dibangun pada masa pemerintah Kolonial Belanda, diperkirakan memiliki luas sekitar $465 \mathrm{~m}^{2}$ dan memiliki halaman yang sederhana. Bangunan poloklinik yang terbuat dari batu dan kayu kini terlihat usang karena bangunan tersebut tidak lagi digunkan seperti dahulu. Terlihat pada bagian pintu masuk bangunan poliklinik, bangunan tersebut sudah tidak memiliki pintu. Bagian atap bangunan terbuat dari genteng, pada bagian plapon juga terlihat ada yang sudah rusak. Bangunan ini sudah tidak dipergunakan lagi sebagai poliklinik. Bangunan poloklinik ini sudah tidak terawat lagi dan dibiarkan kosong sampai sekarang ini.

\section{Bangunan Gudang Barang Perkebunan Desa Tandem Hilir}

Bangunan gudang barang perkebunan desa tandem hilir ini dibangun sekitar abad ke 19 dan memiliki luas sekitar $350 \mathrm{~m}^{2}$ yang dipergunakan untuk penyimpanan barang - barang perkebunan milik perkebunan Desa Tandem Hilir. Bangunan yang berbentuk persegi ini di bagi dalam beberapa ruangan yaitu bagian tempat penyimpanan mesin air, mesin dompeng, mesin babat tanaka, dan alat - alat perkebunan lainnya. 


\section{Bangunan Rumah Manajer Perkebunan Desa Tandem Hilir}

Bangunan rumah manajer ini dibangun pada tahun 1930 an dan memiliki luas sekitar $2500 \mathrm{~m}^{2}$. Bangunan rumah manajer ini memiliki halaman yang luas dan disekitar halaman terdapat tumbuhan yang di tanam untuk memperindah bangunan rumah manajer dan hamparan rumput yang menghijau. Hal ini menandakan bahwa dalam membangun rumah juga memperhatikan lingkungan sekitar rumah, sehingga rumah yang ditempati manajer terlihat sejuk dan nyaman, Bangunan Rumah yang di bangun pada masa pemerintahan Belanda tersebut berbentuk rumah panggung. Bangunan tersebut berpondasikan batu beton yang sangat kokoh, serta berdindingkan kayu. Bagian depan atau pintu masuk dibuat tinggi, dan terdapat beberapa jendela yang memiliki ventilasi yang memanjang dan disekat menbentuk kotak-kotak. Kondisi bangun rumah manajer terlihat masih terawat dengan baik, namun rumah manajer tersebut tidak lagi digunakan sebagai tempat tinggal manajer perekebunan. Bangunan rumah manajer tersebut dibiarkan kosong begitu saja. Bangunan tersebut perlu di perhatikan agar tidak punah dan hancur begitu saja. Karena bangunan yang memiliki nilai sejarah ini wajib dilestariakan.

\section{Bangunan Gudang Pemeraman Tembakau Desa Tandem Hilir}

Bangunan yang di bangun sekitar abad ke 1889 ini memiliki luas diperkirakan $3000 \mathrm{~m}^{2}$. Bangunan gudang pemeraman tembakau berbentuk seperti pondok panjang dan berdindingkan kaca beratapkan seng. Bangunan yang dahulunya digunakan sebagai tempat pengelolaan tembakau sekarang ini tidak lagi digunakan sebagai tempat pemeraman tembakau. Bangunan gudang tembakau ini di biarkan kosong begitu saja. Kondisi bangunan terlihat sangat memprihatinkan, terlihat dari bagian dinding kaca yang sudah pecah. Bagian atap yang mengalami kebocoran sehingga lantai bangunan gedung pemeraman tembakau tersebut tergenai air akibat kebocoran dari atap, tidak hanya itu kayu-kayu tempat pemilihan tembakau juga terlihat sudah rusak dan tidak terawat lagi. Seharusnya bangunan gudang pemeraman tembakau ini dapat perhatian khusus dari pemerintah perkebunan dan masyarakat setempat mengingat bangunan 
gudang pemeraman tembakau ini memiliki nilai sejarah yang begitu penting pada masa tembakau Deli.

\section{Bangunan Rumah Staf Perkebunan Desa Tandem Hilir}

Bangunan rumah staf perkebunan yang dibangun pada masa pemerintahan Kolonial Belanda, di perkirakan memiliki luas sekitar $459 \mathrm{~m}^{2}$ dan memiliki halaman yang sederhana tidak seperti rumah manager yang memiliki halaman yang sangat luas. Bentuk rumah staf perkebunan ini berbentuk sangat sederhana. Atap rumah berbentuk segitiga dan terbuat dari genteng memperlihatkan gaya arsitektur khas belanda dengan tiang rumah bergabung menopang atap bagian teras rumah. Tipe rumah ini dibangun dengan memiliki banyak jendela. Sehingga ventilasi udara dibuat hanya seperti lubang - lubang kecil. Kondisi bangunan rumah staf perkebunan ini masih seperti kondisi aslinya.

\section{Bangunan Mushola Perkebunan Desa Tandem Hilir}

Musholah ini dibangun sekitar tahun 1940 an. Sehingga dapat dilihat bahwa kontruksi bangunan Mushollah ini merupakan bangunan Mushollahpada masa dahulu. Terlihat dari bentuk atap Mushollah dan bentuk teras Mushollahyang terbuat dari batu serta kawat didinding bangunan. Namun, fungsi Mushollahini tidak lagi sebagai tempat beribadah melainkan sebagai rumah baca yang bernama rumah baca nusa dua. Sejak tanggal 30 april 2011 Mushollah beralih fungsi menjadi rumah baca untuk masyarakat Desa Tandem Hilir. Sedangkan tempat beribadah dibangun tepat di sebelah rumah baca nusa dua ini. Bangunan Rumah baca nusa dua masih seperti aslinya tidak ada sedikitpun yang di renovasi.

\section{Bangunan Gedung SMP PAB Desa Tandem Hilir}

Bangunan SMP PAB yang dibangun pada masa pemerintahan Kolonial Belanda. bangunan ini di perkirakan di bangun pada tahun 1940. Bangunan ini digunakan sebagai tempat sekolah untuk anak - anak buruh dan pegawai perkebunan tembakau. Bangunan SMP PAB memiliki luas sekitar $2000 \mathrm{~m}^{2}$, dan memiliki halaman yang 
sederhana untuk bermain bagi anak -anak. Terlihat pada gambar bangunan SMP PAB berbentuk bangunan masa sekarang.

\section{Bangunan Rumah Asisten Perkebunan Desa Tandem Hilir}

Bangunan Rumah asisten perkebunan tembakau ini merupakan salah satu bangunan yang dibangun oleh pemerintah Kolonial Belanda. di perkirakan bangunan ini di bangun sejak abad 19 dan luasnya sekitar $2000 \mathrm{~m}^{2}$. Namun dari hasil penelitian tidak ada yang tahu siapa yang pertama kali menempati rumah asisten pekebunan ini.Bangunan rumah asisten perkebuna $\mathrm{n}$ tembakau tersebut berbentuk rumah panggung yang berbahan dasar kayu, pondasi rumah yang terbuat dari beton atau batu menjadi penyanggah rumah yang megah ini. Halaman rumah yang luas menambah sejuk dan nyamannya bangunan ini. Pintu masuk bangunan rumah asisten di buat lebih tinggi, dan bangunan rumah asisten perkebunan memiliki banyak jendela sehingga tidak ada ventilasi yang di buat pada bangunan ini. Bentuk atap rumah segitiga yang terbuat dari genteng.

\section{Bangunan Perumahan Staf Perkebunan}

Bangunan rumah staf perkebunan ini merupakan salah satu bangunan bersejarah yang ada di Desa Tandem Hilir. Bangunan yang di bangun oleh pemerintah Kolonial Belanda pada saat kejayaan tembakau Deli ini berdiri pada tahun 1940 an dan luasnya sekitar $940 \mathrm{~m}^{2}$. Terlihat pada gambar kontruksi bangunan berciri kahs Belanda yang memiliki dinding terbuat dari batu dan atap terbuat dari genteng. Tipe bangunan rumah staf perkebunan memiliki banyak jendela dan ventilasi di atas jendela hanya membentuk lubang - lubang kecil saja. Halaman rumah yang sederhana membuat rumah terlihat lebih indah.

\section{Rumah Karyawan Perkebunan}

Bangunan rumah karyawan yang di bangun pada masa pemerintahan kolonial Belanda sangatlah sederhana. Bangunan yang menjadi tempat tinggal karyawan perkebunan ini di tempati oleh beberapa keluarga. Bangunan rumah karyawan ini 
hanya terdiri dari satu ruangan saja yang berbentuk persegi panjang, yang menjadi pisahan bagi keluarga adalah dinding penyekat kamar - kamar tidur keluarga karyawan perkebunan.

\section{Upaya Pelestarian Masyarakat dan Pemerintah Terhadap Bangunan Bersejarah di Desa Tandem Hulu dan Tandem Hilir}

Pelestarian yang selayaknya dilakukan oleh pemerintah dan masyarakat setempat dalam menyelamatkan situs sejarah kini semakin tidak dilakukan, karena kurangnya kesadaran dalam memelihara situs sejarah Begitu juga halnya dengan bangunan bersejarah perkebunan tembakau di Desa Tandem Hulu dan Desa Tandem Hilir yang masih ada, seperti yang dijelaskan sebelumnya. Misalnya seperti bangunan bekas gudang pemeraman tembakau di Desa Tandem Hilir yang dibangun pada tahun 1889 yang kini bangunanya terlihat tidak terawat dan dibiarkan kosong begitu saja. Tidak hanya bangunan gudang pemeraman tembakau adayang kondisinya kini tidak lagi terawat bangunan perkantoran administrasi, bangunan poloklinik dan bangunan rumah asisten perkebunan yang seharusnya dijadikan cagar budaya agar tidak musnah begitu saja. Maka dari itu perlu adanya upaya untuk mendata/mendokumentasikan terus dilakukan, misalnya melalui pemugaran, tentang aset daerah berupa peninggalan sejarah yang tidak boleh dimusnahkan agar keberadaan peninggalan sejarah tetap diketahui masyarakat.

Pelestarian peninggalan - peninggalan bangunan bersejarah menjadi hal teramat penting untuk dilakukan. Sebab selain menjadi sebuah catatan tersendiri mengenai kehidupan masa lampau yang pernah berlangsung di suatu daerah tertentu, peninggalan - pinggalan tersebut dapat menjadi lokasi atau objek pembelajaran bagi generasi generasi berikutnya dan upaya menelaah kehidupan yang bermanfaat dan dapat diaplikasikan kembali di kehidupan sekarang. Jika dilihat dari bangunan - bangunan bersejarah di Desa Tandem Hulu dan Tandem Hilir tidak terlihat serius dalam upaya pelestarian bangunan - bangunan bersejarah tersebut, baik itu dari pemerintah daerah mapun dari masyarakat setempat. 
Sampai saat ini upaya untuk melestarikan bangunan - bangunan bersejarah di Desa Tandem Hulu dan Tandem Hilir tidak terlihat secara nyata dan baik dari pemerintah dan masyarakat sendiri. Meksipun dalam hasil wawancara pernah ada pendataan mengenai bangunan - bangunan bersejarah dari masyarakat setempat, tetapi tidak ada tindakan yang di lakukan oleh pemerintah dalam upaya pelestarian bangunan - bangunan bersejarah di Desa Tandem Hulu dan Tandem Hilir itu sendiri. Dalam artian belum ada langkah dan kebijakan khusus untuk melestarikan bangunan bangunan bersejarah yang memiliki arti penting dalam kehidupan di masa lalu.

Jika di tinjau dari aspek historisnya bangunan - bangunan bersejarah di Desa Tandem Hulu dan Desa Tandem Hilir mengandung nilai sejarah yang tinggi, khusunya jika meninjau perkembangan dan sejarah daerah itu sendiri. Oleh sebab itu, pelestarian bangunan - bangunan bersejarah perkebunan Desa Tandem Hulu dan Tandem Hilir. Sejauh ini pihak PTPN II hanya mendata bangunan-banguan sebagai aset dari perkebunan yang mana yang layak digunakan, apabila bangunan sudah tidak layak digunakan maka akan dibiarkan roboh begitu saja. Jika bangunan yang sudah tidak layak digunakan masih ada yang menempati, hal itu menjadi tanggung jawab pemilik rumah untuk merenovasi bangunan tersebut, tidak ada bantuan dari pemerintah perkebunan untuk merenovasi bangunan yang sudah tidak layak digunakan tersebut meskipun bangunan tersebut termasuk bangunan - bangunan peninggalan bersejarah. Dengan kata lain dapat disimpulkan pihak pemerintah perkebunan tembakau Desa Tandem Hulu dan Desa Tandem Hilir hanya membiarkan bangunan - bangunan bersejarah tersebut tanpa ada perawatan terkhusus yang dilakukan oleh pihak pemerintah.

Selain itu, pihak pemerintah perkebunan tembakau tidak memiliki banyak biaya untuk melestarikan bangunan - bangunan bersejarah yang ada di Desa Tandem Hulu dan Desa Tandem Hilir. Hal itu disebabkan, kurangnya pendapatan terhadap bangunan bersejarah perkebunan tembakau disebabkan kualitas tembakau sekarang kurang bagus dan semakin berkurangnya minat Negara Luar dalam membeli tembakau Deli. Sehingga pihak perkebunan ingin mengganti tanaman seperti tanaman tebu dan kelapa 
sawit, Namun dari pihak pemerintah pusat melarang penghapusan penanaman tembakau secara keseluruhan sebab tembakau merupakan ciri khas dari tanaman Sumatera Timur. Walapun pihak perkebunan telah mengalami kerugian besar.

Proaktif pemerintah memang sangat diharapkan secara luas, untuk itu pemerintah terkait harus memiliki program yang jelas agar terlihat dan terasa manfaatnya bagi pembangunan Kebudayaan dan Pariwisata di daerah ini. Pemerintah sebagai plopor menunjukkan minatnya yang tinggi dalam merawat dan melestarikan, masyarakat akan mengikuti jika pemerintah memberi petunjuk agak bermanfaat secara luas. Menjadikan aset bersejarah sebagai Kebudayaan dan Pariwisata dapat di lakukan pada daerah ini. Agar sekolah - sekolah serta intansi pemerintah lainnya menjadikan aset sejarah sebagai media pembelajaran yang relevan dengan tugasnya. Selain itu generasi generasi penerus bangsa dapat mengetahui tentang sejarah lokal daerah meraka pada zaman dahulu hingga sekarang.

\section{PENUTUP}

Dari hasil penelitian yang dilakukan maka dapat disimpulkan bahwa bangunan bangunan bersejarah yang ada di Desa Tandem Hulu yaitu bangunan rumah manajer perkebunan, bangunan perkantoran administrasi perkebunan, bangunan gudang pupuk, bangunan gudang barang, bangunan rumah staf perkebunan, bangunan gudang pemeraman tembakau, bangunan mesjid perkebunan, bangunan kantor afdeeling, dan banguan sekolah SMP Negeri 3 Hamparan Perak. Sedangkan, bangunan - bangunan yang terdapat di Desa Tandem Hilir yaitu bangunan perkantoran administrasi perkebunan, bangunan poliklinik, bangunan gudang barang perkebunan, bangunan rumah manajer perkebunan, bangunan gudang pemeraman tembakau, bangunan rumah staf perkebunan, mushollah perkebunan, bangunan gedung SMP PAB Desa Tandem Hilir, Bangunan Rumah asisten perkebunan dan bangunan perumahan Staf perkebunan.Kondisi peninggalan bangunan bersejarah yang ditemukan oleh penulis saat ini keadaannya ada yang di rawat dengan baik, ada juga yang tidak dirawat sama sekali. Seperti bangunan - bangunan bersejarah yang berada di Desa Tandem Hilir yaitu bangunan perkantoran administrasi, bangunan poliklinik, bangunan gudang pemeraman tembakau dan bangunan rumah asisten perkebunan di biarkan kosong dan 
dapat roboh begitu saja. Berdasarkan penelitian, penulis menemukan pemanfaatan bagi bangunan -bangunan bersejarah ini yaitu sebagai tempat tinggal, kantor, gudang untuk mengelola tembakau dan sekolah. Sebagian bangunan mengalami peralihan fungsi seperti mushola yang berada di Desa Tandem Hilir kini fungsinya sebagai taman baca nusa dua dan bangunan rumah asisten di Desa Tandem Hilir kini digunakan sebagai tempat beribadahnya masyarakat kristiani yang sebagian merupakan pegawai dan staf perkebunan tembakau di Desa Tandem Hilir. Partisipasi masyarakat terhadap bangunan - bangunan bersejarah di Desa Tandem Hulu dan Desa Tandem Hilir tidak ada. Karena tidak berkaitan dengan masyarakat, bangunan tersebut milik pemerintah perkebunan dan tidak bisa di manfaatkan oleh masyarakat setempat. Partisipasi Pemerintah terhadap bangunan - bangunan bersejarah di Desa Tandem Hulu dan Tandem Hilir juga sangat kurang sekali. Di karenakan anggaran yang tidak pernah ada untuk melestarikan bangunan - bangunan bersejarah tersebut. Selain itu, dalam struktur organisasi perkebunan tidak ada petugas pada bagian pemeliharaan heritage.

\section{DAFTAR BACAAN}

Adisasmita Raharjo. (2012). Analisis Tata Ruang Pembangunan. Graha Ilmu. Yogyakarta.

Agustono Budiono. Dkk. (1997). Badan Perjuangan Rakyat Penunggu Indonesia VS PTP II Sengketa Tanah di Sumatera Utara. Akatiga. Bandung

Arsip, Daftar Rekapitulasi Aset Tetap Dan Penyusutan Perjenis Aset Tetap Per September tahun (2016). PT. Perkebunan Nusantara II

Arsip, Kecamatan dalam angka (2013) Hamparan Perak.

Daliman, A. (2012). Metode Penelitian Sejarah. Yogyakarta: Ombak.

Feilden, M. B. (1994). Conservation of Buildings. Oxford : Butterworth - Heinemann Kamus Besar Bahasa Indonesia (KBBI) Online.

Koestoro, Pertanda Lucas. (2008). Mencegah Hancurnya Gedung dan Situs Bersejarah di Medan dan Sekitarnya. Makalah ini Disimpaikan Dalam Seminar Internasional. PUSSIS UNIMED 17 Mei.

Moleong.LexyJ.(2000).Metodelogi Penelitian Kualitatif. Bandung:Rosdakarya

Sjamsuddin Helius. (2007). Metodeologi Sejarah. Ombak. Yogyakarta

Susiana.(2007).Identifikasi Bangunan - Bangunan Peninggalan Bersejarah Di Kabupaten Serdang Bedagai.Medan 